\title{
USING THINK-PAIR-SHARE TO DEVELOP STUDENTS' SOCIAL AND EMOTIONAL COMPETENCIES IN CHEMISTRY LEARNING
}

\author{
Yuli Rahmawati*, Tri Hastuti Budi Utami, Muktiningsih Nurjayadi, and Alin Mardiah \\ Chemistry Education Department, Universitas Negeri Jakarta, \\ Jl. Rawamangun Muka, Jakarta 13220, Indonesia \\ *Correspondence: email: yrahmawati@unj.ac.id
}

Received: April 19, 2018

DOI : 10.20961/jkpk.v5i1.13140
Accepted: January 14, 2020

Online Published: April 30, 2020

\begin{abstract}
The aim of this study was to analyze students' social and emotional competencies through the integration of Think Pair Share (TPS) and a Social and Emotional Learning (SEL) approach to topics related to Acids and Bases. Social and Emotional Learning (SEL) is the process through which children and adults understand and manage emotions, set and achieve positive goals, feel and show empathy for others, establish and maintain positive relationships, and make responsible decisions. The study involved thirty-five $11^{\text {th }}$ grade students in one of a private school in Jakarta and was conducted between January and April 2017. A qualitative methodology was employed to analyze students' social and emotional competencies using interviews, classroom observations, reflective journals, and student worksheets. The application of a SEL approach was carried out by integrating it with a TPS strategy. In the Think, stage students were given the opportunity to explore their understanding of acids and bases and to solve problems individually. In the Pair stage, they could communicate their insights to the group, and in the Share stage, they had occasion to present their group perspectives and respond to others. The five social and emotional competencies found in this study were; self-awareness, self-management, social awareness, relationship management, and responsible decision making. Self-awareness was demonstrated by understanding a student's abilities, their needs, and their self- confidence. Self-management was indicated by a student's ability to manage pressure, plan strategies, and seek help. Social awareness competencies were analyzed through the development of students' attitudes to diversity and how they demonstrated care for friends. Relationship management competencies were identified by observing a student's ability to manage friendships, how they overcame differences, and whether they provided assistance to each other. The responsible decision making competency was determined by observing how students made decisions when trying to solve a problem and whether they were able to plan a strategy when facing pressure. Whilst integrating SEL, the researchers were challenged by the need to empower students, encourage teachers to stimulate students' social and emotional competencies, and to manage time constraints. Integrating SEL into chemistry learning provided opportunities for students to develop their social and emotional competencies through independent thinking activities, group discussions, and presentations to their peers.
\end{abstract}

Keywords: Chemistry Learning, Social Emotional Competences, Social-Emotional Learning, Think Pair Share, Acid-Base Topic

\section{INTRODUCTION}

Social competencies are assessed in the current Indonesian school curriculum, known as Curriculum 2013. The curriculum is based on regulations developed by the Indonesian Ministery of Education and Culture (Permendikbud) and includes graduate competency standards and standards of primary and secondary education. The graduate 
competency standards in Curriculum 2013 involve aspects of spiritual attitudes (KI 1), social attitudes ( $\mathrm{KI} 2$ ), knowledge ( $\mathrm{KI} 3$ ), and skills (KI 4). Students must also be able to face $21^{\text {st }}$-century challenges with a set of skills that include critical thinking and problem solving, creativity and innovation, and communication, and collaboration [1, 2].

Observations were undertaken over a semester at one of the schools in Jakarta as participants in the study. The observation revealed that students in Grade 11 were poorly motivation to learn. These behaviors are identified where some students slept during lessons, group work was challenging, little concerned was shown regarding difficulties with friends, and there were occurrences where special needs students were bullied. Learning motivation is closely related to student attitude. Therefore, the implementation of SEL in the classroom can be used to develop students' social and emotional competencies alongside academic requirements. The approach can be used with all levels of education and genders [3,4,5,6].

Development of social and emotional competence through an SEL approach is done through the application of knowledge, attitudes, and skills needed to understand and manage emotions, set positive goals, show empathy for others, have positive relationships and make responsible decisions [5]. Based on previous research, the application of SEL has a positive impact on learning outcomes and physical health, increases a sense of citizenship, reduces interpersonal violence, improves relationships, and reduces the risk of nonconformity as a critical aspect of achieving success in life $[7,8]$.
The five aspects of emotional and social competencies that are strengthened through the application of SEL are 1) selfawareness - the identification and recognition of one's own emotions, recognition of strengths in self and others, a sense of self-efficacy, and self-confidence, 2) self-management impulse control, stress management, persistence, goal setting, and motivation, 3) social awareness-empathy, respect for others, and perspective taking, 4) relationship management -cooperation, seeking and providing help, and communication, and 5) responsible decision making - evaluation and reflection, and personal and ethical responsibility [9].

Based on the above descriptions, the researchers were interested in implementing SEL integrated with a Think-Pair-Share (TPS) in exploring a topic on Acids and Bases. Research by [10] shows that TPS can help develop students' social attitudes in a multi-ethnicity society such as Indonesia. TPS also increases student motivation and learning outcomes [11]. Thus, this research focused on developing the social and emotional competencies of students at SMA 5 Yadika Jakarta through the integration of SEL with TPS.

\section{METHODS}

The research used a qualitative methodology and an interpretive paradigm to understand and interpret the students' social and emotional competencies during the learning process.

Multiple data collection was achieved through student interviews, classroom observations, reflective journals, and student worksheets. The data obtained was then analyzed in three stages, first by data reduction, 
then data presentation followed by verifications and conclusions [12]. External validity tests established validity, including prolonged engagement, persistent observation, progressive subjectivity, member checking, and negative case analysis.

\section{RESULTS AND DISCUSSION.}

\section{The Integration of SEL with a TPS Strategy}

The integration of SEL and TPS can be seen in Figure 1. Data is collected when students were given a real-life scenario related to the Acid and Base topic. Some scenarios were related to carbonated beverages, cyanide, and soil water $\mathrm{pH}$. The scenarios were designed to stimulate students' social and emotional attitudes, and each ended by posing several problems that needed to be resolved by encouraging students' social and emotional competences.

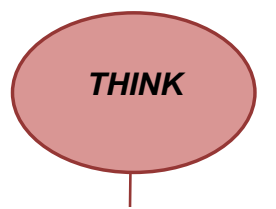

Emerging Competencies

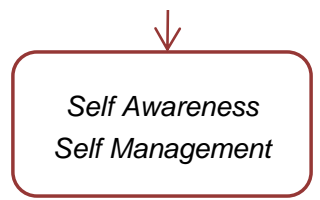

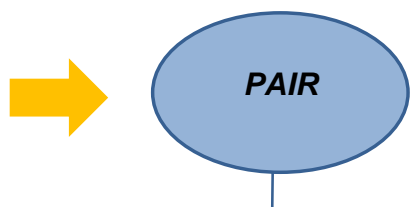

Emerging Competencies

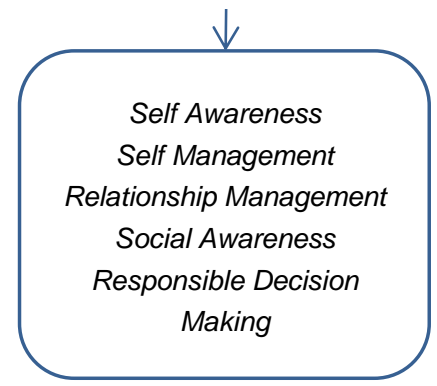

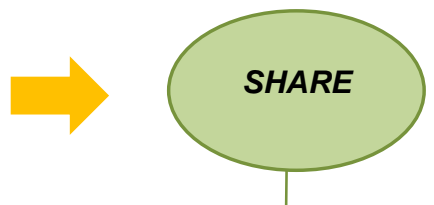

Emerging Competencies

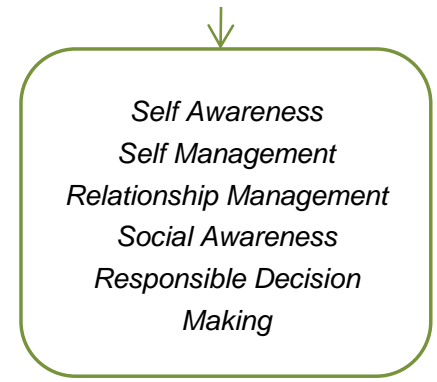

Figure 1. Scheme of implementing Social and Emotional Learning (SEL) with a Think Pair Share strategy

\begin{tabular}{|c|c|c|}
\hline THINK & PAIR & SHARE \\
\hline $\begin{array}{l}\text { - Teacher gives explanation } \\
\text { about acid and base topic. } \\
\text { - Students given a story } \\
\text { related to acid and base } \\
\text { application in daily life. } \\
\text { - Students are given } \\
\text { questions and problems } \\
\text { from the story. } \\
\text { - Students are required to } \\
\text { seek answers to solve the } \\
\text { problem individually } \\
\text { (cheating is prohibited). } \\
\text { (Self awareness and self } \\
\text { management) }\end{array}$ & $\begin{array}{l}\text { - Group making (1 group } \\
\text { consist of } 4 \text { students) } \\
\text { - Students are required } \\
\text { to communicate the } \\
\text { results of the answers } \\
\text { they have worked. } \\
\text { (Self Awareness, Self } \\
\text { Management, Social } \\
\text { Awareness, } \\
\text { Relationship } \\
\text { Management and } \\
\text { Responsible Decision } \\
\text { Making) }\end{array}$ & $\begin{array}{l}\text { - Each group is asked to } \\
\text { present the results of their } \\
\text { discussions to } \\
\text { classmates. } \\
\text { - Groups requested for } \\
\text { presentations of 3-4 } \\
\text { groups. } \\
\text { - Other groups are required } \\
\text { to respond. } \\
\text { (Self Awareness, Self } \\
\text { Management, Social } \\
\text { Awareness, Relationship } \\
\text { Management and } \\
\text { Responsible Decision } \\
\text { Making) }\end{array}$ \\
\hline
\end{tabular}

Figure 2. Relationship of Think Pair Share (TPS) with Student's Social and Emotional Competencies 
The following is an explanation of the social and emotional competencies that emerged at each stage of the Think Pair Share process.

\section{a. Think}

Because students are asked to focus more on finding out and understand their abilities and needs and their ability to achieve those needs, the social and emotional competencies that arise at this stage of the process are self-awareness and self management.

\section{b. Pair}

Students are now working with their peers, so each of the five aspects of social and emotional competencies emerge, namely, self-awareness, self-management, social awareness, relationship management, and responsible decision making. Students are not only managing themselves, but they also need to understand the learning environment and make decisions that they can be accountable for.

\section{c. Share}

At this stage, the five aspects of social emotional competencies are also engaged. Students present answers from their group discussion by expressing their opinions through debate. During this stage, students use self-management and self-awareness strategies as well as social and emotional competencies.

During the implementation of the SEL approach to chemistry learning, the application process became a challenge for researchers whereby students' social and emotional competencies had to be engaged. Time management also needed to be considered due to the study being carried out over a relatively long time. Other essential competencies could not be ignored during that time.

\section{The Social and Emotional Learning (SEL) Implications}

\section{a. Self Awareness}

Students' Self Awareness competencies were analyzed based on many codes that recognized their strengths and limitations, identified self-needs, and whether self-confidence was evident. Samples from student interviews, reflective journals, and worksheets can be seen as follows.

\section{"I acted as a motivator in the group (giving advice and encouraging friends) to be more cooperative in the discussions."}

(Reflective journal of student 19, 03 March 2017)

\section{"I have difficulty in studying the acid and base topic, especially the content related to the formula and the calcula- tions."}

(Interview of student 8, 31 March 2017)

\section{"I understand chemistry with practicum better than theory because practicum can be understood more clearly." (Interview of student 1, 29 March 2017)}

Based on the data, it can be seen that students were able to recognize their strengths and abilities to understand the subject matter better. Students indicated a preference for chemistry learning that is accompanied by a practicum, where they can see things related to chemistry such as tools, chemicals, and chemical processes that occur rather than by theory alone. During a practicum, students were able to motivate and encourage their peers so that the process was more conducive to learning. 
As stated Slavin in [13] that motivation can be more effective if carried out in a group. Group learning with peers raises enthusiasm for learning activities such as discussion, the exchange of ideas, working together to solve problems, and completing set tasks. The influence of peers can make a significant impact on students. Acikgoz in [14] revealed that learning with groups has several advantages, one of which is that it can transmit the enthusiasm and motivation of learning from dominant students to more passive students.

During the learning process, students were given articles related to issues Concernning acids and bases. Providing examples of problems when teaching chemistry can make it easier for students to understand the topic being studied rather than just describing the material.

\section{"In my opinion, liquid cyanide is more dangerous than cyanide in food because we do not know ex- actly how big the cyanide content is, other than that the human body is easier to absorb liquid."}

(Worksheet of student 7, 29 March 2017)

Students can understand the acids and bases topic and provide logical answers when given a case to analyze. The use of articles related to current issues on acids and bases can encourage students to be more enthusiastic about studying chemistry. Also, the TPS strategy requires students to demonstrate self-confidence during the learning process.

\section{b. Self Management}

analysis of students' selfmanagement competencies is done based on how students plan work to achieve results as desired, how they resolve obstacles, their ability to make long-term strategies, how they manage personal and interpersonal pressure, and whether they can seek help when needed.

"If you are forced to drink water with an acidic $\mathrm{pH}$, then the solution is to mix it with something that has a basic $\mathrm{pH}$."

(Worksheet of student 9, 29 March 2017)

"The activity I did during the learning process was to listen to the presentation, to know and understand if it was later given a question by the group that makes a presentation."

(Reflective journal of student 7, 3 March 2017)

Based on the data, better results were achieved in student self-management when studying in groups. Students could organize or plan jobs for the desired outcome during the learning process, and students felt a sense of responsibility to the group. Slavin in [13] stated that groups could influence student motivation and feelings towards learning.

Acikgoz in [14] stated that group learning could help students collaborate to overcome problems they may face in the learning process. Group learning in this study was done using the TPS strategy where students individually thought about problems provided by the teacher they then compared and harmonized their responses through group discussion and, in the third phase of the strategy, they presented their solution to other students in the class.

The following interview data demonstrate student self-management of personal and interpersonal pressures in chemistry learning. 
"With the group discussion, it makes me need to be able to reduce my embarrassment when speaking in front of the class"

(Interview of student 6, 29 March 2017)

"If there is a topic that I do not understand, I will ask my father because he is a science teacher or asks my friend who has better understanding."

(Interview of student 18, 3 March 2017)

Group learning requires students to be more accepting of different opinions and to be more cooperative during the learning process so that optimal results for the group can be obtained. Based on the responses above, it appears that students were able to overcome group learning obstacles throughout the learning process. Acikgoz in [14] argues that one of the advantages of group learning is that it increases work responsibilities, and builds integrity and self-confidence.

$21^{\text {st-century learning requires students }}$ to explore deep understanding. The Indonesian Minister of Education and Culture [15] states

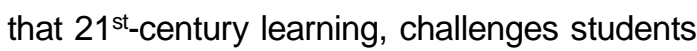
to analyze and be able to think metacognitively about their knowledge as they pass through the 4-C stages of Critical Thinking, Creativity, Collaboration, and Communication [2]. When students know their limitations and ask for help from others who have a better understanding, then the student has gained collaborative knowledge. Students then conveying their enhanced experience to their peers through presentations.

\section{c. Social Awareness}

When learning social awareness competencies in the classroom, a lack of ability to socialize and accept the circumstances of the environment becomes problematic. Students often find it difficult to appreciate a diversity of opinions during discussions, and there can be a lack of care for classmates who have difficulties during the learning process.

\section{"My group and I allow each group member to express their opinions one by one "}

(Reflective journal of student 2, 3 March 2017)

Based on the results from students' reflective journals, appreciating diversity, and accepting conditions of distinction in the learning environment is evident. The sense of tolerance, sympathy, and empathy developed during the learning process can, hopefully, be translated into everyday life.

According to [16], core competencies in every learning area is contained in $\mathrm{KI}-2$ so that the learning process undertaken and the findings obtained are in line with the Government's desire to create $21^{\text {st-century }}$ learning that builds a social attitude of tolerance and respect for difference [15].

Social Awareness competencies include caring about others and their environment.

"If my closest people consume carbonated drinks, I will tell them the adverse effects of the drink, and advise them not to take it excessively." (Worksheet of student 21, 3 February 2017)

At the conclusion of the learning process, a teacher would expect students to have excellent cognitive skills as well as good spiritual and social attitudes. Through group learning, students are able to care more about the group's ability to obtain a optimal score. Acikgoz in [14] states that one of the other advantages of group learning is that it increases student sensitivity and concern for 
their learning environment, which in this study is a group created by teachers using TPS.

\section{d. Relationship Management}

Relationship Management competencies can be problematic when cooperation, mutual assistance, and a positive attitude towards helping others who have difficulties are absent. Students' Relationship Management competencies in this study were analyzed based on their ability to relate to friends, how they engaged in cooperative learning and working together in groups, whether they assisted those in need, and how they overcame differences of opinion.

\section{"I prefer a bunch of people who are wasted (not being liked) because I can motivate them to better." \\ (Interview of student 7, 24 March 2017)

\begin{abstract}
"When we get group assignments, we divide the task according to each member's ability so that all members can work properly "
\end{abstract}

(Interview of student 1, 24 March 2017)

The above response indicates that students can establish friend-ships and to cooperate and appreciate others better when in a group learning situation. They become more aware of others and can develop a shared group vision. Slavin in [14] states that in the process of group learning creates an atmosphere of cooperation and mutual respect towards the group so that the goals of group work are achieved [13]. Collaboration and mutual assistance is an expected learning competency in [16] where students are encouraged to socialize and cooperate in community activities.

\section{"I would tell that there is cyanide content in some kind of food and}

\section{how to consume it so that people can avoid the adverse impacts gen- erated by cyanide.}

(Worksheet of students 18, 29 March 2017)

According to the data, students already had an awareness of other's needs and a desire to assist those who needed help in learning activities and daily life. Slavin in [13] states that through the process of group learning, a sense of empathy and knowledge about the condition of the environment will be more developed.

\section{"If there are differences of opinion, we deliberate first, then vote to choose the most appropriate aswer, and the voting process can accelerate the time of work" \\ (Interview of student 8, 31 March 2017)}

The above description highlights that students often have differing opinions about their learning that become more evident during group discussions. Discussion of current issues created dynamic and open conversations where students were able to overcome disagreements that arose in the learning process by using TPS.

\section{e. Responsible Decision Making}

Responsible decision making during learning is often hindered by a lack of student confidence in answering questions and completing tasks set by the teacher. A lack of responsibility, concern, and application during discussions can also lead to poor results in the study of chemical materials.

Responsible Decision-Making competence was analyzed by Identifying the decisions made by students, how they applied problem-solving skills when making 
decisions that affect individuals, schools, and society, and through discussion.

\section{"When making a decision, first we gather accurate data; usually the data is obtained from the members opinion or various sources (Internet, books, teachers), then we discuss to make the most appropriate answers."} (Reflective journal of student 5, 3 March 2017)

"The way to make a decision is to share opinions among group members, then determine the answer that is most appropriate for the problem and which can be accepted by logic." (Interview of student 13, 3 March 2017)

From the descriptions above, it appears that students can identify the decisions they take during the learning process in their daily life and when working on questions. Group learning with TPS applies the 21st-century learning model where students in Indonesia must practice and apply the characteristics of integrity, cooperation, independence, and nationalism. In group learning, students must be able to demonstrate integrity in the discussion process and to be able to convey and justify the results of a discussion. This practice achieves the ideals and goals of $21 \mathrm{st}$ century learning in Indonesia as stipulated in Permendikbud number 21 of 2016 regarding the stages of learning and also the characteristics of the learning process [2].

Slavin in [13] states that in group learning, students develop an attitude of responsibility, providing opinions and answers to get the best results for the group [13]. By giving responsible answers, students begin to feel more valued by their classmates and teachers throughout the learning process.

"How to overcome the pH of tap water that is acidic by neutralizing the water using alkaline compounds, such as adding with lime that is alkaline "

(Worksheet of student 12, 29 March 2017)

"When debating, we appoint friends who are good at talking and try to refute the opinions of other groups with answers that are logical and in accordance with the theory."

(Interview of student 17, 3 March 2017)

The explanation above shows that students were able to solve problems through collaborative decision-making to get the best results. The responsible implementation decision-making is aligned with the aims of 21st-century skills contained in Permendikbud number 21 of 2016 regarding the four learning stages, commonly known as 4-C [2].

Students can use strategies to get the best results from completing group assignments. [13] states that in group learning, each group will work together through the learning process to develop the best strategy to get the best results. Students who are dominant in groups tend to be the more motivated students, and are able to influence other students to be motivated as well.

\section{"I will reduce the level of soda in carbonation drinks because if I close the company, what about the fate of its workers, it is feared that there will be more unemployment in our country."}

(Worksheet of student 21, 3 February 2017)

From the results above, it appears that students were able to make decisions that could be accounted for, and they were able to provide answers that demonstrate an understand of the conditions of their environment. The answers given by students provided an overview of the different perspectives students held and how they responded to problems 
such as the issue of carbonated drinks. Students were able to be open-minded and answer questions responsibly and with integrity. These results support the hypothesis that TPS learning can support character education as described in Permendikbud number 21 of 2016 regarding the expectation that the characteristics of integrity and responsibility will emerge from the learning process[2].

Acikgoz in [14] states that group learning can heighten a student's sense of responsibility in problem-solving activities because students feel they have to of their best in front of their peers and teachers during the learning process.

In undertaking chemistry learning that is conducted in groups using TPS, students are given scientific articles, and group assignments allow students' Social and Emotional competencies to emerge and develop. This means that learning with TPS is not only a dynamic and exciting process, but it is also aligned with the 2013 curriculum launched by the Indonesian government following the ideals of the Indonesian state to develop the character of the student.

\section{CONCLUSIONS}

\section{Conclusions}

Based on the results of this research, the integration of Social and Emotional Learning (SEL) with Think Pair Share can develop students' social and emotional competencies in chemistry learning. Emotional and social competencies that arise and develop in students during the research process are Self Awareness, Self Management,
Social Awareness, Relationship Management, and Responsible Decision Making.

The development of self-awareness competencies is demonstrated by the ability of students to recognize their strengths and limitations, identify their needs, and have confidence. In self-management, the development of student competencies is characterized by students' ability to manage / plan work for desired results, overcome obstacles and create strategies for the long term, manage personal and interpersonal stresses, and seek help when needed. The social awareness competency shows that students have been able to appreciate diversity and care for others. In relationship management, students can demonstrate the ability to make good relationships with friends, engage in cooperative learning and work together in groups, provide assis-tance to those in need, and resolve differen-ces of opinion that arise during learning. Developments in responsible decision-making competencies are characterized by students' ability to identify decisions made, apply skills in problem-solving when making decisions, identify strategies used to deal with pres-sures, and make responsible decisions that affect individuals, schools, and society.

The challenges faced in integrating Social and Emotional Learning (SEL) in chemistry learning are ensuring student participation in learning, the ability of researchers to stimulate students' social-emotional competencies, and time management because the development of student attitudes requires a relatively long time. 


\section{Suggestions}

To align and support the aim of Curriculum 2013 to develop student character, the researchers anticipate that research on developing student attitudes in learning chemistry will continue to be developed. The integration of Social and Emotional Learning (SEL) can be readily used in other chemistry topics according to the characteristics of the learning materials. And models of teaching can be varied to include a wide range of media.

Further research using the Think Pair Share strategy can raise important issues in daily lives and will assist in the development of scientific articles that stimulate interest and help develop students' learning potential. A SEL approach with TPS ensures learning is more fun, meaningful, innovative, and inclusive. In this kind of learning environment, social and emotional competencies can be optimally developed and become increasingly embedded as an integral aspect of a student's personality and identity in their everyday life.

\section{REFERENCES}

[1] Kemendikbud. Permendikbud No. 20 tentang Standar Kompetensi Lulusan Pendidikan Dasar dan Menengah. Jakarta: Kemendikbud. 2016.

[2] Kemendikbud. Permendikbud No. 21 tentang Standar Kompetensi Isi Pendidikan Dasar dan Menengah pasal 1 ayat (2). Jakarta: Kemendikbud. 2016.

[3] E, Jessie. Empowering Metacognition Through Social-Emotional Learning: Lesson for the Classroom. Singapore: CENGAGE Learning. 2009.

[4] J. A Durlak, R. P Weissberg, A. B Dymnicki, R. D Taylor, \& K. B Schellinger, "The Impact of Enhancing Students' Social-Emotional Learning:
A Meta-Analysis of School-Based Universal Interventions." Society for Research in Child Development Inc., vol 82, no.1, pp. 405-432, 2011.

DOI: 10.1111/j.1467-624.2010.01564

[5] R. P. Weissberg, J. A. Durlak, C. E. Domitrovich \& T. P. Gullotta, Social and emotional learning: Past, present, and future. Handbook of social and emotional learning: Research and practice. New York, NY: Guilford,2015.

[6] V. Coelho, V. Sousa, \& A.P. Figueira.. "The Impact of a School Based Social and Emotional Learning Program on the Self-Concept of Middle School Students". Revista de Psicodidáctica, Vol.19, (2), 347-365, 2014 ISSN: 11361034 elSSN: $2254-4372$.

DOI:10.1387/RevPsicodidact.10714

[7] M. J. Elias, J. E. Zins, R. P. Weissberg, K. S. Frey, Greenberg, T. M. Haynes, M. Norris, K. Rachael, S. Stone, E. Mary \& P. T. Shriver, Promoting social and emotional learning: Guidelines for educators. Alexandria, VA: Association for Supervision and Curriculum Development, 1997.

[8] J. E. Zins, R. P. Weissberg, M. C. Wang \& H. J. Walberg (Eds.). Building academic success on social and emotional learning: What does the research say? New York: Teachers College Press, 2004.

DOI: 10.1080/10573560600992837

[9] CASEL Leadership Team. Safe and Sound: An Educational Leader's Guide to Evidence-based Social and Emotional Learning (SEL) Programs. Chicago: CASEL, 2003.

[10] D. T. Boleng \& A. D. Corebima, "Cooperative learning models having better potency to improve the social attitude of multiethnic senior high school students at Samarinda," Indonesia. Journal of Educational Research and Reviews, vol. 2, no. 3, pp. 36-44, 2014.

[11] Hetika, I. Farida \& Y. P. Sari, "Think pair share (TPS) as method to improve student's learning motivation and learning achievement." Dinamika 
Pendidikan, vol. 12, no. 2, pp. 125-135, 2017.

DOI: 10.15294/dp.v12i2.13561

[12] Miles \& Huberman. Qualitative Data Analysis: An Expanded Sourcebook. New York: Sage Publication. 1992.

[13] P. Quinn, Cooperative Learning, and student Motivation. Education and Human Development Master's Theses. The College at Brockport: State University of New York. 2006.
[14] S. Altun, "The Effect of Cooperative Learning on Students' Achievement and Views on the Science and Technology Course". International Electronic Journal of Elementary Education, vol. 7, no.3, pp. 451-468. 2015.

[15] Kemendikbud. Permendikbud No. 24 Tahun 2016 tentang Kompetensi Inti dan Kompetensi Dasar Lampiran . Jakarta: Kemendikbud, 2016.

[16] Kemendikbud. Permendikbud No. 24 Tahun 2016 tentang Kompetensi Inti dan Kompetensi Dasar Pasal 2, Ayat (5). Jakarta: Kemendikbud, 2016. 